\title{
ACHIEVING EFFECTIVE VISITOR ORIENTATION IN EUROPEAN MUSEUMS. INNOVATION VERSUS CUSTODIAL
}

\begin{abstract}
.
The context in which museums operate has evolved considerably over the last few decades, while the challenges they face have increased. The current need for museums to augment their own revenue and improve their performance coupled with the transformation of cultural models towards more experiential services has led many to adopt a consumer orientation in an effort to make museums and their collections increasingly accessible to visitors. This visitor orientation is more than just a wish to bring culture closer to the public, but rather a desire to understand visitors' demands and thus adapt to their expectations. This paper seeks to explore the relation between visitor orientation and performance in museums. Specifically, the study focuses on technological innovation and tradition as two alternative strategies to respond to visitor expectations. An empirical study was conducted for a sample of 491 European museums. Evidence is found to support the notion that the impact of visitor orientation on economic and market performance depends on how visitors' needs are perceived and on museums' commitment to either innovation or tradition and custody. Whereas technological innovation has a positive impact on revenue and economic performance, the impact of custodial orientation is negative. Custodial orientation only proves effective in market terms in large museums but does not prove effective in economic terms, for either small or large museums. This paper offers a guide as to
\end{abstract}


how to deal with visitor orientation in cultural and heritage organizations. Although an orientation to innovate geared towards satisfying visitor needs would seem the logical way for museums to increase visitor numbers, an approach involving too much innovation, often leading museums to becoming shows, has been widely criticized.

Keywords.

Museums; Consumer orientation; Custody; Innovation; Cultural heritage management 


\section{Introduction and research aims}

In recent years, the economic crisis and cutbacks in public budget have forced museums and other heritage institutions to seek new sources of funding and have also encouraged the search for greater management efficiency and effectiveness. In this search, cultural institutions are more concerned with captivating visitor emotions and exceeding their expectations with each experience, as a means of achieving enhanced performance.

The issue of how to approach visitor orientation in cultural and heritage organizations is one which sparks a variety of conflicting and often controversial opinions. Certain museums have opted to innovate and display their collections in a way that has more of an impact on the visitor. Other museums, by contrast, fear the dreaded Disneyfication of culture and prefer to display exhibits in the conventional manner, in an effort to preserve and maintain the museum's cultural mission. This defence of the conventional model of a museum was reflected for instance in the change of management in the London Science Museum in 2005, whose curator Lindsay Sharp was "accused of Disneyfying an august institution with razzle-dazzle interactive displays and showbiz exhibitions" [1].

Given this context, the aim of the present research is to explore the role of innovation and custody in the relation between visitor orientation and performance in the case of museums. We posit the existence of two alternative means of making visitor orientation effective in cultural and heritage organizations in both economic and market terms. Visitor orientation may lead museums to invest in technological innovation, which would enhance visitor 
appeal and satisfaction in addition to entailing increased costs. Visitor orientation may also encourage museums to pay greater attention to their cultural and conservation mission to satisfy those visitors who have certain expectations with regard to what they want to see [2]. We feel that exploring the role of innovation as opposed to conservation orientation enables us to clarify the lack of consensus in the literature regarding the impact of consumer orientation on performance in the case of cultural and heritage organizations.

\section{Theoretical and conceptual background: from the economy of experiences to innovation in museums.}

In an economic environment like today's, in which firms are immersed in mature and highly competitive markets and in which consumers are increasingly well informed, are more critical and demand more customized products, it is essential to secure a shift to a paradigm which is not only based on satisfying consumer needs but which also strives to comprehend how consumer perceptions trigger emotions and feelings and how these directly affect performance [3]. This new paradigm or new economy is an economy of experience. This new philosophy assumes that what consumers seek is an experience, namely "memorable events that engage each customer in an inherently personal way" [4]. As Wu [3, p. 107] points out "in the experience economy period, to bring the best experience, it's essential for future enterprises to attentively design and let the consumers willingly pay for experience". 
In 1998, Pine and Gilmore coined the term "economy of experience" in their article Welcome to the experience economy, and in the book published a year later [6] they observed that the experience component of the economy is growing rapidly, and outstripping the service sector. They further explained the difference between service and experience as follows: "When a person buys a service, he purchases a set of intangible activities carried out on his behalf. But when he buys an experience, he pays to spend time enjoying a series of memorable events that a company stages as in a theatrical play to engage him in a personal way" [6, p.2]. The aforementioned authors have identified four types of experience, including entertainment, education, escapist and estheticism. The ever-capricious and flighty demand for experiences and the latter's shifting nature make innovation a key tool in the economy of experience as a means of constantly offering new and appealing experiences and staying competitive in a growing and increasingly global market $[7,8]$.

Museums, like many other cultural institutions, have become part of the experience economy. Although museums have traditionally been described as institutions focused primarily inwards on the growth, care, and study of their collections, they are gradually adopting a more entrepreneurial management approach aimed at serving the public [9]. This change is being driven by a range of factors. Changes in demand and cultural consumption patterns, particularly sparked by the digital revolution, are obliging cultural organisations to consider new ways of relating to their audiences and catering to emerging tastes $[10,11]$. As regards financing, museums face 
cutbacks and greater accountability for government funding, with increased emphasis on public value and efficiency, as well as growing pressure to find new ways of obtaining and boosting earned income [10,12,]. Museums are thus being increasingly forced to operate under market conditions and to compete with one another as well as with other cultural and leisure activities in the struggle to secure resources and visitors. In order to cope with competition, museums need to offer a high-quality museum experience if they are to retain and enlarge their power of appeal [13]. They must also seek to adapt their services and activities to the wide-ranging interests, needs, and expectations of current visitors if they are to give them a satisfying, educational, and valuable museum experience [13,14]. In the current environment, the concern for visitor experience means that museums must look beyond the traditional focus on collections and even the more recent focus on information and education. As Kotler and Kotler point out [15, p. 276], generating experiences in museums involves developing "activities in which visitors can directly participate, intensive sensory perception combining sight, sound, and motion, environments in which visitors can immerse themselves rather than behave merely as spectators, and out-of-the-ordinary stimuli and effects that make museum visits unique and memorable".

In order to provide visitors with these experiences, museums need to engage in innovative presentation and interpretation techniques to maintain both the educational and recreational roles of modern museums [16, 17]. Innovativeness in business is defined as the degree to which a firm creates new products and 
services using accumulated knowledge from consumers, competitors, and technology [18]. This definition of innovation implies that it not only refers to newness and unique differences from competitors, but also to improvements and changes in certain aspects of the services provided and developments in the technology used. In fact, innovation in museums may involve multiple aspects: technological innovation, organizational procedures, displays and new techniques of exhibition, educational, diffusion and promotion programs, as well as new relationships with visitors and other publics, new management models, etc.

As regards visitor oriented innovation, in museums the latter seeks to go beyond visitor expectations by surprising or exciting them. This is true of the Tate Modern which shows little hesitation in embracing the exhibition-show approach. It has opted for major themes and constant turnover by organizing temporary exhibitions and by drawing the greatest possible benefit from activities run parallel to the museum (bookshops, restaurants) in order to capture funding [19]. Indeed, others view innovations and technology as the means to accomplish the museum's cultural mission. This may be the case of the Reina Sofia museum, which has embraced an innovative program and a clear use of new technologies [20]. Museums have opted to implement innovations in an effort to reach new markets or create new experiences by using new technologies already tried and tested in other areas. In the current paper, we specifically focus on these technological innovations.

\section{Literature review and hypotheses}


In our work we are particularly concerned with clarifying what exactly is meant when referring to visitor related performance in museums. McMillan, et al. and Gainer and Padanyi [21,22] feel that the outcome of any marketing strategy applied to museums must be assessed in both financial and non-financial terms. Following on from these approaches, we consider two kinds of performance: economic and market. In addition to weighing up obtained revenue, the economic aspect must also take account of factors such as how to increase visitor numbers, boost the number of friends of the museum, generate funds through temporary exhibitions or create jobs. All of these economic goals are geared towards ensuring the museum's survival and viability. For its part, the market dimension of performance refers to the benefits obtained by individuals, such as enhanced visitor interest, their satisfaction, loyalty or the museum's image.

As we have explained, the current need for museums to be more profitable and to increase their own revenue has led many to adopt new models of management in an effort to make the museum and its collections more accessible to visitors. These models involve improving visitor experience through a consumer orientation. This visitor orientation is more than just a wish to bring culture closer to the public, but rather a desire to understand visitors' demands and thereby adapt to their expectations.

The dilemma facing cultural and heritage organizations is deciding whether the best way to respond to visitors' expectations is by providing the product they would anticipate or by adding value thereto. Visitors to the Prado know that they will see Las Meninas. Yet, can the value of their visit be enhanced by offering 
other unexpected services? Some museums feel that it can, and have opted to innovate and break with conventional forms of presenting exhibitions. We therefore see how museums innovate in a technological sense by using digital catalogues, large databases, online activities, touch screens, and virtual web visits, which have already been tried and proved in other settings enabling museums to reach out to new or generate new expectations, interests and experiences for the visitor [23,24]. In fact, Han et al., [25] established that one key aspect of consumer orientation philosophy is to provide added value to the consumer, in other words an ongoing willingness and proactive approach towards satisfying consumer demands. Siu et al. [26] state that offering and renewing novel and meaningful services affects customer perception of a museum's investment in relationships. Technological innovation signals a museum's efforts and desire to satisfy its customers' needs creatively. As a result, we posit that:

\section{H1: Visitor orientation has a positive impact on technological innovation.}

The positive link between innovation and performance has been demonstrated for cultural organizations [27]. Given the surge in cultural tourism and the diversification of the target audience museums are aiming to reach, new technologies may help to attract a wider public (tourists, as opposed to those who may be termed "connoisseurs"), specific groups (students, teachers, families, amongst others), as well as offering services to other target audiences (the press, travel agencies). If we add to this the fact that information and communication technologies applied to museum management can help to improve efficiency in terms of costs, we are accepting that innovation in museums can contribute 
towards enhancing economic performance. Further, technological innovations applied to visitor experience provide a more agreeable and satisfying experience to those with more of a tourist profile. We therefore posit that:

H2. Technological innovation has a positive impact on museums' market performance $(\mathrm{H} 2 a)$ and economic performance $(H 2 b)$.

In contrast to technological innovation, other museums assume that visitors will value exhibitions for their artistic, historical or heritage significance, which in turn entails placing a greater emphasis on conservation, research and the acquisition of new works [28]. Custodial orientation is thus perceived as a tendency on the part of museums to focus on their mission over and above market demands.

This mission-focused orientation may at first sight appear insufficient, yet is essential in a museum context. Visitor orientation may encourage organizations to respond to visitor expectations by focusing on the value of the collection itself, offering the cultural product (as opposed to a leisure product) that visitors expect to see. As a result, the museum will centre its attention on producing content through conservation and research linked to collections and organising exhibitions. Miguel Zugaza, director of the Prado museum is convinced that there is no better offer available than the collection itself. Housing Goya, Velázquez or El Greco ensures that visitors will return to the museum time and again. Temporary exhibitions are staged as a sideline to the great masters. Nicholas Penny, director of the National Gallery, favours the spread of knowledge and feels that the museum's treasure lies within its walls and that it is not worth attempting to attract new visitors by offering extravagant activities [29]. As a result, 
consumer orientation in cultural and heritage organizations urges the latter to adapt to certain visitor expectations, and leads them to focus on the product currently available, respecting their mission to preserve and safeguard the heritage in their care.

H3. Visitor orientation has a positive impact on custodial orientation.

Custodial orientation, in so far as it reflects a commitment to the production of content is able to satisfy a more intellectual and elitist public, who understand art and culture and who are able to enjoy the works for what they are, without the need for any trimmings, and to appreciate the research and investigative work carried out by the museum. It seems logical to assume that such audiences will be satisfied and enthusiastic about their visit. Yet, the kind of audience which such a strategy is aimed at (researchers, student, teacher, lovers of art and culture), represents an extremely small number. Not being geared towards a wider audience may undermine the museum's ability to engage new visitors who are driven more by entertainment. In this sense, an orientation towards custody might have a negative impact on the museum's ability to generate revenue and on its economic performance. Nevertheless, custodial orientation may also prove to be a viable alternative in large museums. Indeed, in response to the crisis and cutbacks in museum funding, some of the major museums with large collections have given up their commitment towards innovation and have fallen back on their own collections [30]. Major museums, particularly those devoted to fine arts, have once again opted to resort to their own collections, safe in the knowledge that exhibitions of artists such as Picasso, Van Gogh, the impressionists or Velázquez 
guarantee visitor numbers and economic viability. In short, whereas it may be viable for major museums to adopt an approach based solely on the conservation and presentation of their collections, such an orientation might well prove insufficient to attract visitors in the case of smaller museums. We thus posit that:

H4. Custodial orientation has a positive impact on museums' market performance (H4a) and on large museums' economic performance (H4b) and a negative impact on small museums' economic performance ( $\mathrm{H} 4 \mathrm{c})$.

The hypotheses proposed are shown in Figure 1.

Insert here Figure 1

\section{Empirical analysis}

\subsection{The sample}

The empirical work is based on an analysis of the information provided by a sample of British, French, Italian and Spanish museums. Information was gathered through a survey sent by mail to the museum directors. The sample population considered comprised 3500 museums (800 British, 1000 French, 800 Italian and 900 Spanish) included in the webpages of the respective Ministries of Culture. The total number of responses obtained during the process once incomplete questionnaires had been removed came to 491 (110 British, 142 French, 104 Italian and 135 Spanish). The museums in the sample cover a range of different thematic areas: archaeology, contemporary art, decorative arts, fine arts, science and technology, natural sciences, ethnography and anthropology or 
history. In Table 1 we show the museums' characteristics.

Insert here Table 1

\subsection{Measurement variables and model estimation}

Visitor orientation variables, orientation to custody and technological innovation were measured using reflective scales with five position indicators (from 1, "completely disagree" to 5, "completely agree"). The visitor orientation scale was based on the proposal of Narver and Slater [31] although the indicators were adapted to a museum setting taking into account the works of Balabanis et al., [32] and Caruana et al., [33,34]. Custodial orientation was created ad hoc, and includes two items reflecting the fact that the museum's main aim is to maintain and preserve the collection and its desire to engage in projects to preserve cultural heritage. To measure technological innovation we used a four indicator reflective scale reflecting the museum's degree of involvement and interest in adopting new resources and technologies to display works or for dealing with visitors.

To validate the reflective scales we conducted a confirmatory factorial analysis. The goodness of fit indicators proved suitable $\left(\chi^{2}(32)=92.700 \quad(p=0.000)\right.$; $\mathrm{RMSEA}=0.063 ; \mathrm{GFI}=0.963 ; \mathrm{AGFI}=0.937 ; \mathrm{CFI}=0.980 ; \mathrm{NFI}=0.971)$, and the factor loadings took values above 0.65 (see Table 2), thereby enabling us to confirm the convergence of these scales. Given that we compare two groups of museums (large and small museums), we performed a multi-group confirmatory factor analysis which ensured the configural and metric invariance of the measurement models of each group [35]. Finally, to measure economic and 
market performance, we took eight indicators. Economic performance was measured as the increase in revenue and visitors, the creation of jobs or accomplishing financial goals. To measure market performance we used four indicators which consider the centre's increased standing and prestige as well as the enthusiasm and satisfaction evidenced by visitors. For each variable (economic performance and market performance) we created the corresponding indices as the arithmetic mean of the respective indicators.

\section{Insert here Table 2}

Table 3 shows the correlation matrix and the reliability indicators for each variable. As can be seen, all the correlations between the indicators are below the extracted mean variance of the respective variables. This enabled us to obtain the discriminant validity of each of the measures [36].

Insert here Table 3

To estimate the proposed hypotheses we conducted an SME analysis. Since we propose differences between large and small museums, we performed a multigroup analysis. We previously divided the sample into two groups according to museum size. Museum size was measured by the number of employees, a measure used in numerous studies as an indicator of organizational size [37,38]. We consider small museums as those with less than 15 employees (313 museums) and large museums those having 15 or more (132 museums).

Although our aim is to estimate the indirect effect of visitor orientation on performance through a custodial orientation and technological innovation, in the 
estimated model we also included the direct effect so as to ascertain whether mediation is total or only partial. Figure 2 and 3 show the common metric standardized solution $\left(\chi^{2}(123)=252.75, \mathrm{p}=0.000 ;\right.$ RMSEA $=0.066 ; \mathrm{CFI}=$ 0.962; NFI $=0.928$.

To determine the differences amongst the groups, each path was tested sequentially, in each case comparing the constrained model (with the fixed parameter) and the non-constrained model. The significance of the differences between the groups for each coefficient is shown in Table 4 .

\begin{tabular}{c}
\hline Insert here Figure 2 \\
\hline Insert here Figure 3 \\
\hline Insert here Table 4 \\
\hline
\end{tabular}

\section{Results}

In the light of these findings, we accept that visitor orientation contributes directly to enhancing market and economic performance in the case of large museums, as a result of which the mediating effect of technological innovation and custodial orientation will only prove partial. For small museums, the direct effect of visitor orientation on market performance is also significant and we accept partial mediation. However, the direct effect on economic performance is nonsignificant, the mediating effect in this case therefore being total.

As posited in our hypotheses, visitor orientation is linked to two differing museum strategies: technological innovation (H1) and custodial orientation (H3). However, 
the impact of these strategies on performance differs. With regard to the technological innovation, its effect on market performance and on economic performance is positive and significant ( $\mathrm{H} 2 \mathrm{a}$ and $\mathrm{H} 2 \mathrm{~b}$ are confirmed). In other words, for both large and small museums, the technological innovation enhances visitor numbers and revenue as well as museum visitor interest and satisfaction.

As regards custodial orientation, we find that its effect on performance differs between small and large museums. Custodial orientation has a positive impact on large museums' market performance, although in the case of small museums, the effect is non-significant. Hypothesis H4a is therefore only partially supported. As regards economic performance (increased revenue and meeting financial goals), the effect of custodial orientation proves negative for small museums ( $\mathrm{H} 4 \mathrm{~b}$ is supported), but is non-significant for large museums ( $\mathrm{H} 4 \mathrm{c}$ is rejected).

In general terms, it is noticeable that whereas visitor orientation is effective for both small and large museums when they adopt a strategy oriented to innovation, it is not effective if they adopt a strategy oriented to custody, except in terms of market performance and only in the case of large museums.

\section{Discussion and conclusion}

Findings show that visitor orientation impacts both museums' tendency to innovate as well as an orientation towards custody and conservation. A greater visitor orientation encourages such organizations to pinpoint new needs and new audiences, which in turn leads to increased innovation in museums, wherein differentiated products are introduced in response to a constant adaptation to 
shifting visitor needs [39]. At the same time, responding to visitors interested in gaining an insight into the historical, artistic and cultural riches means museums must not overlook their mission to preserve and maintain heritage. These two approaches, however, lead to differing results. The study evidences that innovation in museums has a positive and significant effect on economic and market performance. By contrast, custodial orientation has a positive and significant effect on market performance (enhanced reputation and standing for the museum coupled with greater visitor satisfaction) only in the case of large museums, yet does not lead to improved economic performance (increased revenue, more visitors, etc.). In short, although, a more cultural approach to the presentation of collections, based on research, may satisfy one part of the public (the most elitist in cultural terms), the lack of visitor-tourist orientation, in other words, addressing the mass public, may reduce revenue due to the inability to attract new audiences.

The empirical evidence to emerge from the present study reveals that museums' commitment to cater to visitor needs and wishes contributes to enhancing performance. Yet, how can visitors be satisfied? Thousands visit the Louvre to see the Mona Lisa, or the Reina Sofía museum to see the Guernica or the Prado to see Las Meninas. Would visitors prefer museums to innovate or are they satisfied with what they already have? Some visitors might well wish to see innovations and would be excited at the prospect of what new things the museum might be able to provide, whereas others would hope to find what the museum has always offered, and might belittle or even scorn any kind of "technological" intrusion that 
might detract from the essence of art. In sum, visitor orientation reflected in greater innovation is not necessarily the only way forward, or even the best way of improving performance in museums and cultural organizations.

Yet, our study does evidence that the impact of visitor orientation on economic performance differs when this orientation is reflected through an investment in technological innovation or through a commitment to the current collections. Moreover, the consequences are different for large and small museums. Whereas innovation has a positive impact on revenue and economic performance, the impact of custodial orientation is negative. Custodial orientation proves efficient in market terms only in large museums but does not prove efficient in economic terms either for small or large museums. Focusing on a more exclusive audience does not generate revenue.

This double perspective of a museum's role (innovation versus custody; tourism versus culture; mission versus benefits) is in some way related with the age-old overlap and indeed conflict between art and market or between culture and business. When Warhol began to promote not himself but also pop art, museum curators felt that pop art was commercial and that any art which had business connotations bore little relation to museums. A more recent example is that of the Japanese artist Takashi Murakami whose work has to some extent become a product for the luxury market [40]. The art-market debate aside, we feel that in their policies and planning, museums should strive to be more accessible to a wider audience and above all to reach out to visitors who do not tend to frequent museums. Museums which seek to provide added value to their visitors whilst 
increasing their sources of revenue will be better placed if they merge their traditional activities with a more business-like approach, in which technological innovation no doubt plays a key role. Indeed major museums such as the Prado, National Gallery, Louvre, or Thyssen make a clear distinction between exhibitions geared towards visitors-tourists which become blockbusters and generate vast amounts of revenue, and those which respond more to a concern for conservation, research and study, but which only focus on a minority section of the market and which might even make a loss. Both approaches to the market are valid and even complementary to a certain extent, although the results they provide differ.

\section{Acknowledgements}

This work is framed within the Research Project SEJ2007-67095/ECON funded by the Department for Research and Management of the National R\&D\&I Plan (Ministry of Science and Innovation).

\section{References}

[1] The Times Online, Museum peace after the Sharp shooting?, july 28, 2005.

[2] C.W. Sheng, M.C. Chen, A study of experience expectations of museum visitors, Tourism Management 33 (1) (2012) 53-60.

[3] Q.Wu, Marketing strategy adjustment and marketing innovation in the experience economy era, Contemporary Logistics, 6 (2012) 107-110.

[4] B.J. Pine II (2003). "En la economía de la experiencia, el trabajo es teatro", 
World 60, pp. 1-4. Retrieved from:

http://www.strategichorizons.com/media/pdf/iWorld\%200305\%20Trabajo\%20e s\%20Tea .pdf

[5] B.J Pine, J.H. Gilmore, Welcome to the experience economy, Harvard Business Review, 764 (1998) 97-105.

[6] B.J Pine, J.H. Gilmore, The experience economy, Harvard Business School Press, Boston, 1999.

[7] P Darmer, J. Sundbo, Introduction to experience creation, in J. Sundbo, P. Darmer (Eds.), Creating Experiences in the Experience Economy, Edward Elgar, Cheltenham, 2008, pp. 1-12.

[8] J.Sundbo, Innovation in the experience economy: a taxonomy of innovation organisations, The Service Industries Journal, 294 (2009) 431-455.

[9] S. E. Weil, From Being about Something to Being for Somebody. The ongoing transformation of the American museum, Daedalus 128 (1999), 229258.

[10] H. Bakhshi, D. Throsby, Culture of innovation. An economic analysis of innovation in arts and cultural organisations, NESTA, London, 2010.

[11] D. Throsby, The Economics of Cultural Policy, Cambridge University Press, Cambridge, 2012.

[12] S. Jaffry, A. Apostolakis, Evaluating individual preferences for the British Museum, Journal of Cultural Economics 35 (2011) pp 49-75. 
[13] E. M. Reussner, Strategic management for visitor-oriented museums, International Journal of Cultural Policy 9 (2003) 95-108.

[14] Z. Doering, Strangers, Guests, or Clients? Visitor Experiences in Museums, Curator 42 (1999) 74-87.

[15] N. Kotler, P. Kotler, Can Museums be All Things to All People?: Missions, Goals, and Marketing's Role, Museum Management and Curatorship, 18(2000) 271-287.

[16] P.H. Welsh, Re-configuring museums, Museum Management and Curatorship, 20 (2005) 103-130.

[17] B. Taheri, A. Jafari, K. O’Gorman, Keeping your audience: Presenting a visitor engagement scale, Tourism Management 42 (2014) 321-329.

[18] R.Deshpandé, J.U. Farley, F.E. Webster, Corporate culture. Customer orientation, and innovativeness in Japanese firms: a quadrad analysis, Journal of Marketing 57 (1993) pp. 23-37.

[19] El País, El museo tira de fondo de armario, december 28, 2009. http://www.elpais.com/articulo/cultura/museo/tira/fondo/armario/elpepicul/2009 1028elpepicul_1/Tes. Accessed December 2011.

[20] El Mundo, El Reina Sofía se abre a Goya y se renueva por dentro con la ruptura del orden cronológico, May 27, 2009. http://www.elmundo.es/elmundo/2009/05/26/cultura/1243337238.html. Accessed December 2011. 
[21] K. McMillan, K. Money, A. Money, S. Downing, Relationship marketing in the not-for-profit sector: an extension and application of the commitment-trust theory, Journal of Business Research 58 (2005) 806-818.

[22] B. Gainer, P. Padanyi, The relationship between market-oriented activities and market-oriented culture: implications for the development of market orientation in nonprofit service organizations, Journal of Business Research 58 (2005) 854-862.

[23] S. Styliani, L. Fotis, K. Kostas, P. Petros, Virtual museums, a survey and some issues for consideration, Journal of Cultural Heritage 10 (2009) 520-528.

[24] M. Carrozzino, M. Bergamasco, Beyond virtual museums: Experiencing immersive virtual reality in real museums, Journal of Cultural Heritage 11 (2010) $452-458$.

[25] J. Han, H. Kim, R. Srivastava, Market orientation and organizational performance, is innovation a missing link?, Journal of Marketing 62 (1998) 3045.

[26] N.Y.M Siu, T.J.F. Zhang, P. Dong, and H.Y. Kwan, New services bonds and customer value in customer relationship management: The case of museum visitor, Tourism Management, 36 (2013) 293-303.

[27] G. Voss, M. Montoya-Weiss, Z. Voss, Aligning innovation with market characteristics in the nonprofit professional theatre industry, Journal of Marketing Research 43 (2006) 296-302.

[28] J. Tobelem, The marketing approach in museums, Museum Management and 
Curatorship 16 (4) (1997) 337-354.

[29] El País, Interview: Nicholas Penny Director de la National Gallery de Londres, Los museos son fuente de conocimiento, no de espectáculo, juin 11, 2008.

http://www.elpais.com/articulo/cultura/museos/fuente/conocimiento/espectaculo /elpepicul/20080611elpepicul_1/Tes. Accessed December 2011.

[30] E. De Diego, Muy malos tiempos para el arte, El País.com, april 20,2010. http://www.elpais.com/articulo/cultura/malos/tiempos/elpepicul/20100420elpepi cul_2/Tes. Accessed December 2011.

[31] J.C. Narver, S.F. Slater, The effect of a market orientation on business profitability, Journal of Marketing 54 (4) (1990) 20-35.

[32] G. Balabanis, R.E. Stables, H.C. Phillips, Market orientation in the top 200 British charity organizations and its impact on their performance, European Journal of Marketing 31 (8) (1997) 583-603.

[33] A. Caruana, B. Ramaseshan, M.T. Ewing, The marketing orientationperformance link: some evidence from the public sector and universities, Journal of Nonprofit Public Sector Marketing 6 (1) (1998a) 63-82.

[34] A. Caruana, B. Ramaseshan, M.T. Ewing, Do universities that are more market-oriented perform better?, International Journal of Public Sector Management 11 (1) (1998b) 55-70.

[35] J.B. Steenkamp, H. Baumgartner, Assessing Measurement Invariance in Cross-National Research, Journal of Consumer Research 25 (1998) 78-90. 
[36] C. Fornell, D. Larcker, Structural equation models with unobservable variables and measurement error, Journal of Marketing Research 18 (1) (1981) $39-50$.

[37] J.E. Ettlie, R\&D and global manufacturing performance, Management Science 44 (1998) 1-12.

[38] S. Sengupta, Some approaches to complementary product strategy, Journal of Product Innovation Management 15 (1998) 352-367.

[39] D. Prajogo, A. Sohal, The relationship between TQM practices, quality performance, and innovation performance, International Journal of Quality \& Reliability Management 20 (8) (2003) 901-918.

[40] El País Semanal, El arte de la nada, december 20, 2009. http://www.elpais.com/articulo/portada/arte/nada/elpepusoceps/20091220elpeps por_12/Tes. Accessed December 2011. 
Figure 1

\section{Proposed model and hypotheses}

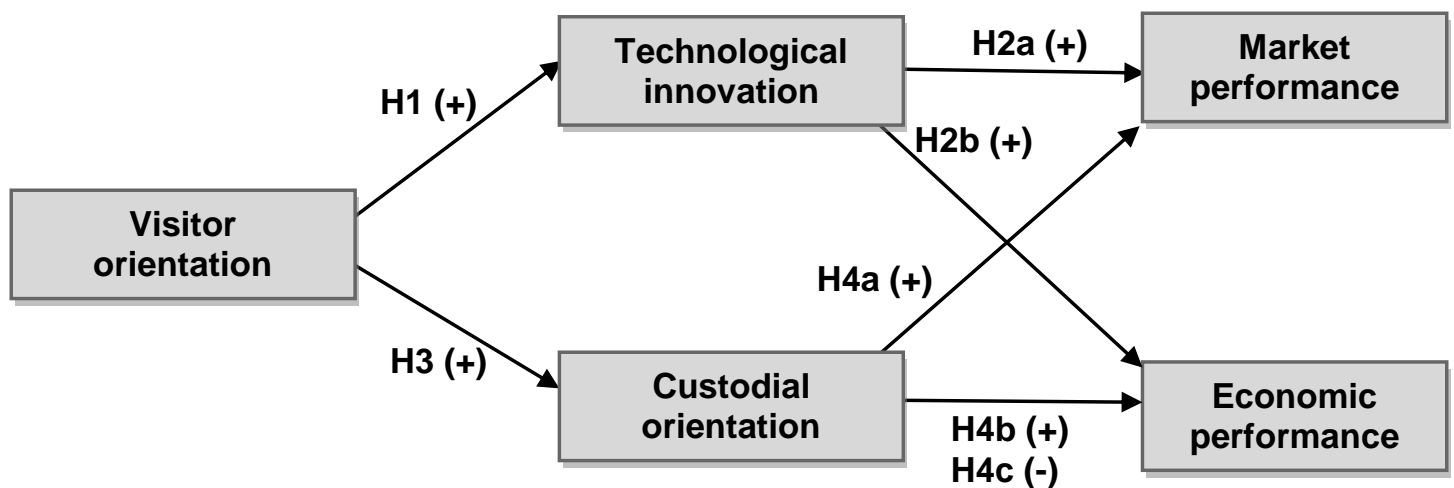


Figure 2

Estimation of the proposed model (Small museums)

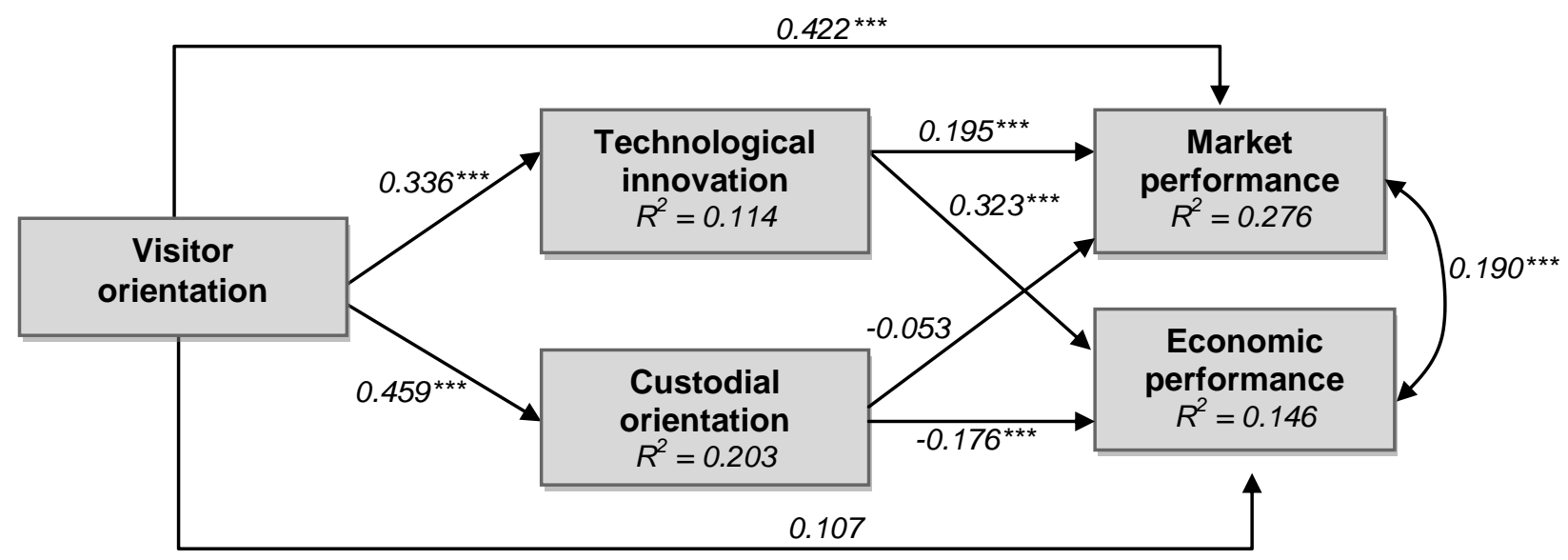


Figure 3

Estimation of the proposed model (Large museums)

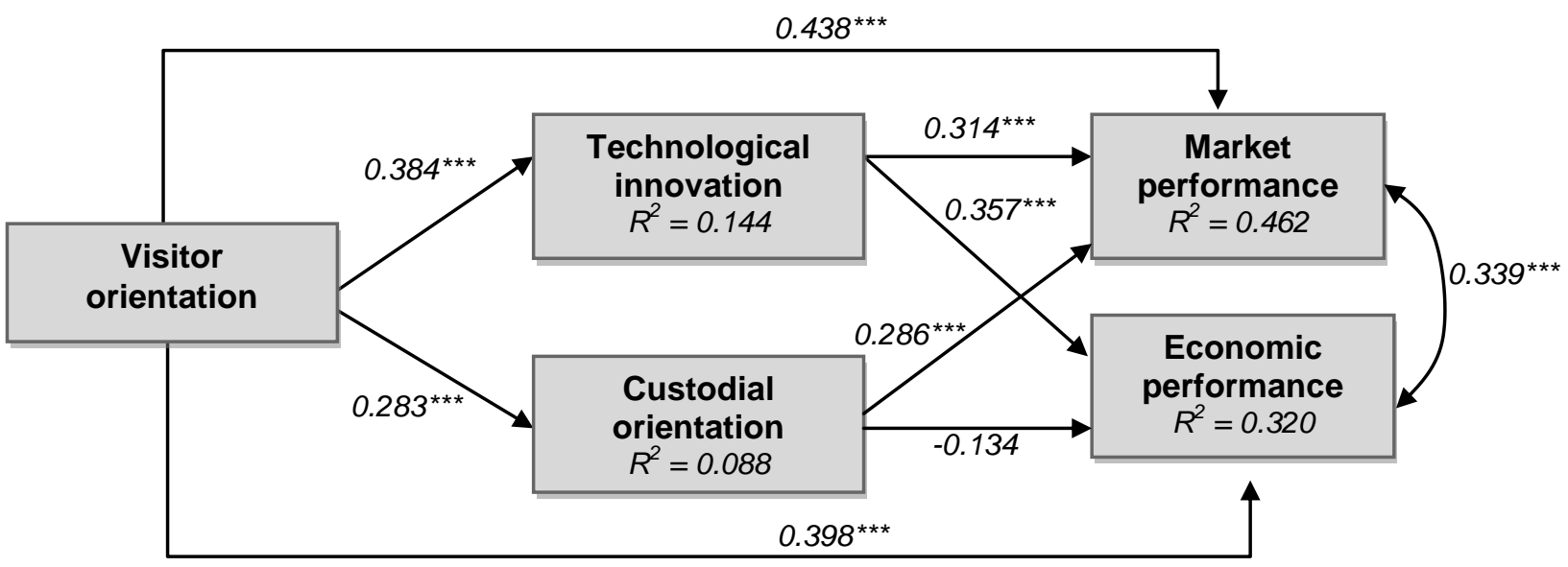


Table 1

Description of the sample

\begin{tabular}{|c|c|c|c|c|c|c|}
\hline \multicolumn{2}{|l|}{ Type of museum(*) } & Management & \multicolumn{2}{|c|}{ Visitors per year } & \multicolumn{2}{|c|}{ Employees } \\
\hline Archaeological & $27.3 \%$ & Public $71.7 \%$ & $<5,000$ & $25.2 \%$ & $<5$ employees & $48.3 \%$ \\
\hline Contemporary Art & $9.0 \%$ & Private $27.1 \%$ & $5,000-10,000$ & $16.8 \%$ & From 5 to 9 & $12.8 \%$ \\
\hline Decorative Art & $12.8 \%$ & & $10,000-25,000$ & $20.8 \%$ & From 10 to 15 & $10.6 \%$ \\
\hline Fine arts & $25.9 \%$ & & $25,000-50,000$ & $15.8 \%$ & From 16 to 25 & $9.4 \%$ \\
\hline House-Centre & $3.9 \%$ & & $50,000-100,000$ & $9.4 \%$ & From 26 to 50 & $10.4 \%$ \\
\hline Science and technology & $8.8 \%$ & & More than 100,000 & $12 \%$ & More than 50 & $8.5 \%$ \\
\hline Natural sciences & $10.6 \%$ & & & & & \\
\hline Place & $9.6 \%$ & & & & & \\
\hline Specialised & $10.4 \%$ & & & & & \\
\hline Ethnography \& anthropology & $16.1 \%$ & & & & & \\
\hline History & $25.5 \%$ & & & & & \\
\hline Other & $5.7 \%$ & & & & & \\
\hline
\end{tabular}

(*) These categories are not exclusive. Several museums are included in more than one category. 
Table 2

Measuring variables. Descriptive statistics and AFC

\begin{tabular}{|c|c|c|}
\hline Latent and measurement variables & Mean $(S D)$ & $\begin{array}{c}\text { Lambda } \\
(a)\end{array}$ \\
\hline \multicolumn{3}{|l|}{ Visitor orientation } \\
\hline Museum strategy is based on those aspects which we feel may create value for the visitor & $4.18(0.882)$ & (b) \\
\hline The museum's goals are geared towards visitor satisfaction & $4.30(0.883)$ & 0.715 \\
\hline We endeavour to keep abreast of changes so as to assess their impact on visitors' needs & $4.01(0.970)$ & 0.849 \\
\hline Seeking to pinpoint visitors' needs and expectations is a constant process & $3.91(1.016)$ & 0.827 \\
\hline $\begin{array}{l}\text { Strategies aimed at gaining an advantage over other museums when seeking resources is } \\
\text { based on an understanding of visitors' needs }\end{array}$ & $3.58(1.080)$ & 0.676 \\
\hline \multicolumn{3}{|l|}{ Technological innovation } \\
\hline $\begin{array}{l}\text { At the museum we are deeply committed to using new resources and technologies to assist } \\
\text { the visiting public }\end{array}$ & $3.66(1.117)$ & 0.710 \\
\hline $\begin{array}{l}\text { In general, we have incorporated numerous technical innovations at the museum in recent } \\
\text { years }\end{array}$ & $3.24(1.209)$ & 0.867 \\
\hline We are one of the leading museums in the use of technical resources & $2.77(1.219)$ & 0.814 \\
\hline $\begin{array}{l}\text { We cooperate with other institutions or firms to improve the technology and innovations } \\
\text { implemented at this museum }\end{array}$ & $3.08(1.265)$ & 0.720 \\
\hline \multicolumn{3}{|l|}{ Custodial orientation } \\
\hline $\begin{array}{l}\text { Our main goal is to conserve and preserve the historical and cultural heritage held by our } \\
\text { centre }\end{array}$ & $4.46(0.862)$ & 0.767 \\
\hline $\begin{array}{l}\text { We are interested in developing projects which enable us to maintain the perennial nature } \\
\text { of our assets }\end{array}$ & $4.44(0.838)$ & 0.904 \\
\hline \multicolumn{3}{|l|}{ Market performance } \\
\hline Over the last three years our centre has enhanced its prestige and reputation & $4.00(0.969)$ & \\
\hline Visitors display enthusiasm and satisfaction after the visit & $4.35(0.717)$ & \\
\hline Many visitor return or recommend the visit to others & $4.20(0.815)$ & \\
\hline The centre contributes to enhancing visitor interest & $4.06(0.816)$ & \\
\hline \multicolumn{3}{|l|}{ Economic performance } \\
\hline Over the last three years the centre's own revenue has increased & $3.12(1.356)$ & \\
\hline Over the last three years jobs have been created & $2.74(1.551)$ & \\
\hline Over the last three years the number of visitors has grown & $3.50(1.341)$ & \\
\hline Over the last three years our centre has comfortable met its financial goals & $3.07(1.239)$ & \\
\hline
\end{tabular}

(a) Standardised coefficients.

(b) Items eliminated. 
Table 3

Correlation matrix and reliability

\begin{tabular}{lccccccc}
\hline & $C R$ & $A V E$ & $\begin{array}{c}\text { Visitor } \\
\text { orientation }\end{array}$ & $\begin{array}{c}\text { Custodial } \\
\text { orientation }\end{array}$ & $\begin{array}{c}\text { Technological } \\
\text { innovation }\end{array}$ & $\begin{array}{c}\text { Market } \\
\text { performance }\end{array}$ & $\begin{array}{c}\text { Economic } \\
\text { performance }\end{array}$ \\
\hline Visitor orientation & 0.82 & 0.67 & 0.82 & & & & \\
Custodial orientation & 0.82 & 0.69 & 0.433 & 0.83 & & & \\
Technological innovation & 0.86 & 0.61 & 0.335 & 0.145 & 0.78 & $n . a$. & $n .371$ \\
Market performance & n.a. & n.a. & 0.497 & 0.298 & 0.379 & $n$ \\
Economic performance & n.a. & n.a. & 0.246 & -0.067 & 0.360 & 0.399 \\
\hline
\end{tabular}

(*) The main diagonal shows the square root of the extracted variance for the reflective variables 
Table 4

Test of differences between groups

\begin{tabular}{lccc}
\hline & $\begin{array}{c}\chi^{\mathbf{2}} \text { (constrained } \\
\text { model) }\end{array}$ & $\left.\chi^{\mathbf{2}(\mathbf{1})(\mathbf{p} \text {-value) }}\right)^{\mathbf{a}}$ & Differences \\
\hline Visitor orientation $\rightarrow$ Technological innovation & 252.92 & $0.17(0.680)$ & Non-significant \\
Visitor orientation $\rightarrow$ Custodial orientation & 255.14 & $2.39(0.122)$ & Non-significant \\
Visitor orientation $\rightarrow$ Market performance & 252.77 & $0.02(0.887)$ & Non-significant \\
Visitor orientation $\rightarrow$ Economic performance & 258.26 & $5.51(0.019)$ & Significant \\
Technological innovation $\rightarrow$ Market performance & 253.89 & $1.14(0.286)$ & Non-significant \\
Technological innovation $\rightarrow$ Economic performance & 252.83 & $0.08(0.777)$ & Non-significant \\
Custodial orientation $\rightarrow$ Market performance & 261.85 & $9.10(0.003)$ & Significant \\
Custodial orientation $\rightarrow$ Economic performance & 252.88 & $0.13(0.718)$ & Non-significant \\
\hline${ }^{\mathrm{a}}{ }^{2} \chi^{2}$ (non-constrained model) $-\chi^{2}$ (constrained model). & & &
\end{tabular}


Table 5

Direct, indirect and total effects

\begin{tabular}{lcccccc}
\hline & \multicolumn{3}{c}{ Small museums } & \multicolumn{3}{c}{ Large museums } \\
\cline { 2 - 7 } & Direct & Indirect & Total & Direct & Indirect & Total \\
effect & effect & effect & effect & effect & effect \\
\hline Visitor orientation $\rightarrow$ Market performance & 0.443 & 0.043 & 0.486 & 0.397 & 0.182 & 0.579 \\
& $* * *$ & - & $* * *$ & $* * *$ & $* * *$ & $* * *$ \\
\hline Visitor orientation $\rightarrow$ Economic performance & 0.111 & 0.029 & 0.140 & 0.368 & 0.092 & 0.460 \\
& - & - & $* * *$ & $* * *$ & $* * *$ & $* * *$ \\
\hline
\end{tabular}

(a) Standardized parameters. (***) Significant effects $(\mathrm{p}<0.01)$ 
Table 6

Tests of the mediating effects (Sobel test)

\begin{tabular}{lcccc}
\hline & \multicolumn{2}{c}{ Small museums } & \multicolumn{2}{c}{ Large museums } \\
\cline { 2 - 5 } & Test & p-value & Test & $p$-value \\
\hline Visitor orientation $\rightarrow$ Technological innovation $\rightarrow$ Market performance & 2.789 & 0.005 & 2.558 & 0.011 \\
Visitor orientation $\rightarrow$ Custodial orientation $\rightarrow$ Market performance & -0.841 & 0.799 & 2.114 & 0.034 \\
Visitor orientation $\rightarrow$ Technological innovation $\rightarrow$ Economic performance & 3.766 & 0.000 & 2.716 & 0.007 \\
Visitor orientation $\rightarrow$ Custodial orientation $\rightarrow$ Economic performance & -2.570 & 0.010 & -1.230 & 0.219 \\
\hline
\end{tabular}

